1 Student at the University of Colorado School of Dental Medicine, Aurora-Colorado, United States of America

${ }^{2}$ Associate Professor at the Federa University of Rio Grande do Norte UFRN, Natal-RN, Brazil.

${ }^{3}$ Collaborate Professor at the State University of Ponta Grossa - UEPG Ponta Grossa-PR, Brazil

${ }_{4}^{4}$ Associate Professor at the Federal University of Rio Grande do Norte UFRN, Natal-RN, Brazil.

${ }^{5}$ Associate Professor at the State University of Paraiba - UEPB,

Araruna-PB, Brazil.

${ }^{6}$ Associate Professor at the Federal University of Rio Grande do Norte UFRN, Natal-RN, Brazil.

Corresponding author:

Cláudia Lobelli

Address: 123 S Granby CT

Aurora Colorado 80012 ,

United States of America

Phone number: +16024322602

E-mail : claudialobelli@gmail.com

Received: July 12, 2018

Accepted: October 28, 2018

\section{Intraoral findings in newborns: prevalence and associated factors}

Cláudia Lobelli Chandler ${ }^{1}$, Isabelita Duarte Azevedo², Manoelito Ferreira Silva Junior ${ }^{3}$, Johnnatas Mikael Lopes ${ }^{4}$, Manuel Antonio Gordón-Núñez ${ }^{5}$, Silvana Alves Pereira ${ }^{6}$

Aim: To investigate the prevalence of intraoral characteristics and associated factors with neonatal and parent variables in a group of Brazilian newborns. Methods: This cross-sectional study with a descriptive and inferential approach, whose data was obtained through clinical examination, interview and the collection of medical record information. The sample was selected from babies up to three days old, of both sexes, and born between January and December 2013 in the Ana Bezerra University Hospital, in the city of Santa Cruz-RN, Brazil. The exposure variables included neonatal (sex, weight, gestational age, type of delivery and Apgar score) and parent (presence of systemic disease(s), drug use and consanguinity between the parents) variables. Descriptive analysis and Poisson regression were performed to estimate the ratio of gross and adjusted prevalence of intraoral findings (Epstein pearls, Bohn's nodule, dental lamina cyst and ankyloglossia) with the neonatal and parent variables $(p<0.05)$. Results: Of a total of 168 examined newborns, $56.5 \%$ $(n=95)$ were male. The most prevalent intraoral feature was the fibrous cord of Magitot, $62.5 \%(n=105)$, and the most frequent alteration was Epstein pearls, 44.6\% $(n=75)$. Female gender was a factor for Bohn's nodule (OR=0.90; $95 \% \mathrm{Cl}: 0.82-0.99)$, and no tobacco use by the father was a protective factor for Epstein pearls (OR=0.73;95\% Cl:0.55-0.97). Additionally, lower mother's age, between $20-34$ years of age $(O R=1.58 ; 95 \% \mathrm{Cl}: 1.07-2.35)$ and under 19 years of age $(O R=1.61 ; 95 \% \mathrm{Cl}: 1.03-2.52)$ increases the chance of having Epstein pearls. Conclusion: There was a high prevalence of alterations in the newborns' oral cavities and there were associations between neonatal and parent variables.

Keywords: Infant, newborn. Oral manifestations. Pediatric dentistry. 


\section{Introduction}

Newborns have some standard features, as well as physiological changes in their oral cavity, dependant on their developmental phase ${ }^{1,2}$. Although many of the oral conditions are of a transitional nature, it is of paramount importance that the involved professionals monitor and identify all findings to avoid the administration of unnecessary therapy ${ }^{3}$. Furthermore, it is important that professionals know how to recognize and diagnose abnormalities in the early stages to reassure the parents and, when necessary, establish the appropriate treatment ${ }^{1,4}$.

The most prevalent morphological characteristic is the fibrous cord of Magitot, a structure in the form of a fibrous cord, flaccid to the touch, and located in the alveolar ridge ${ }^{4}$ (Figure 1A). Its presence contributes to the jaw's sealing by assisting in suction, and its disappearance in the oral cavity indicates the period of dental eruption ${ }^{4}$.

The labial frenulum is a connective tissue structure that extends from the lips to the alveolar process, with the possibility of having apical, palatal or buccal insertion to the rim $^{5}$ (Figure 1B). The labial frenulum may have normal features, or be shorter and/or thicker, resulting in ankyloglossia, which limits movement of the tongue and may lead to breastfeeding problems ${ }^{6}$ (Figure $1 \mathrm{C}$ ). When both the labial and the lingual frenulum are abnormal, thus limiting the ability to feed, frenectomy surgery must be considered?

In addition to the normal morphological characteristics, abnormalities can be found, such as the presence of oral mucosal cysts, also called inclusion cysts. The cysts located on the median palatine raphe are called Epstein pearls, which are derived from remnants of epithelial tissue ${ }^{8}$ (Figure $2 \mathrm{~A}$ ). Bohn's nodules are remnants of tissue and mucous glands and are located above the gingival flange on both the buccal and the lingual, as well as on the palate, away from the median palatine raphe (Figure 2B). When located on the dental ridge of the maxilla and mandible, a cyst is known as the dental lamina cyst, which originates from the remnants of the dental lamina ${ }^{8}$ (Figure 2C). Another change that can be observed in the newborn's oral cavity is the presence of natal and neonatal teeth. The prevalence of these teeth is low 7,9 and has a predilection for females ${ }^{1}$.
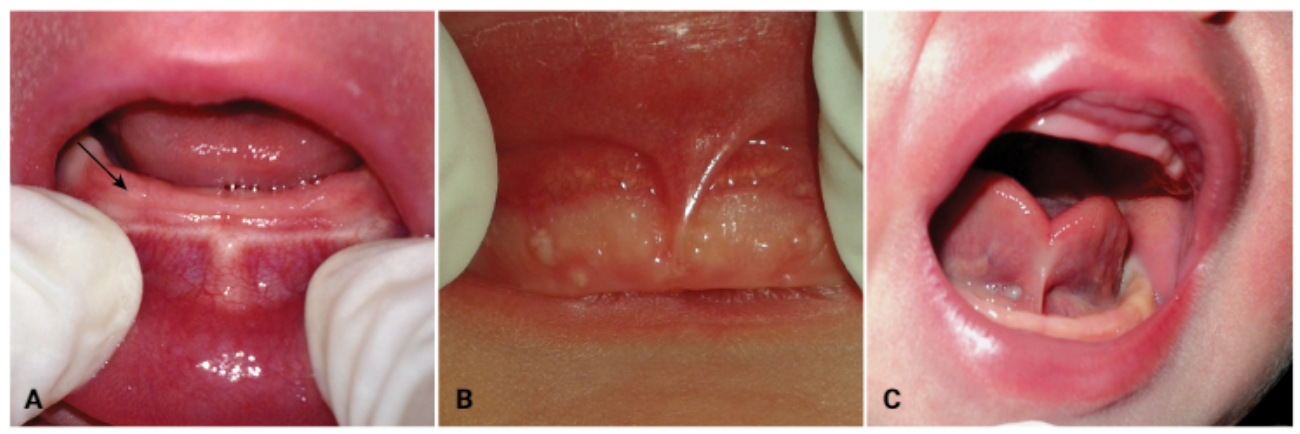

Figure 1. A: Fibrous Cord of Magitot, located on the newborn's lower flange. B: Insertion of the labial buccal frenulum to the alveolar ridge. C: Ankyloglossia. Photography: by researcher. 


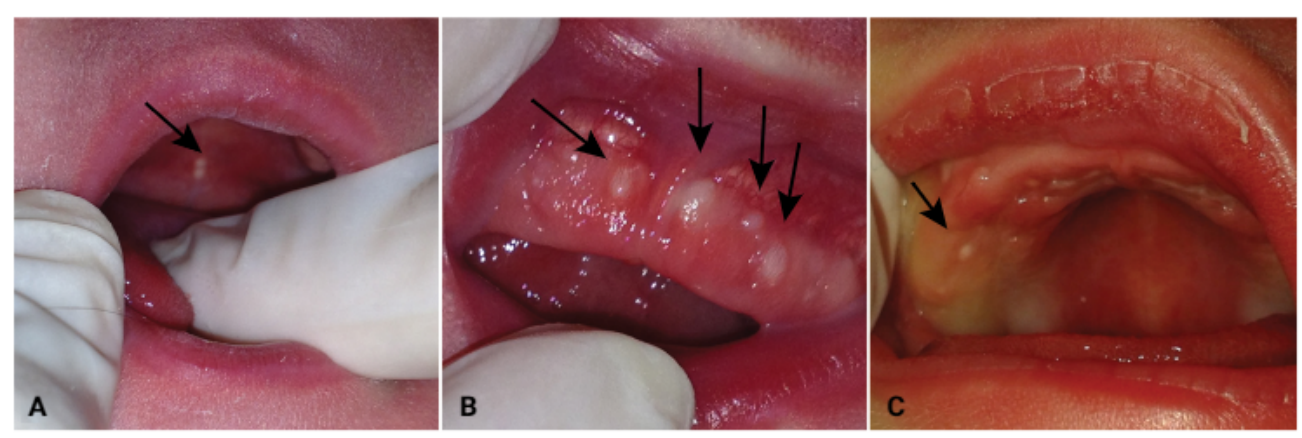

Figure 2. A: Epstein pearl, located on the hard palate, two in number, white in color. B: Bohn's nodule located in the buccal alveolar ridge, four in number, white in color. C: Dental lamina cyst, white in color. Photography: by researcher.

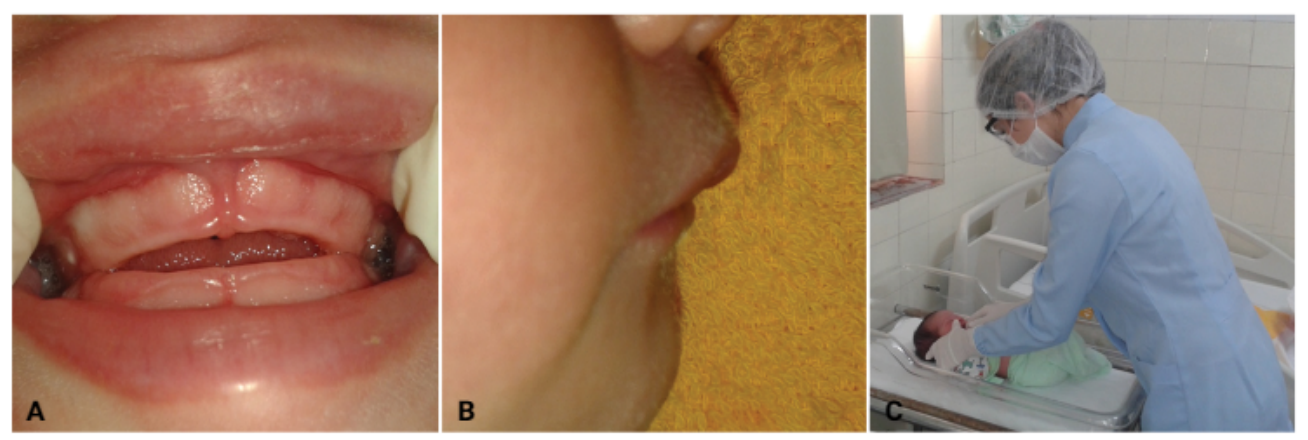

Figure 3. A: Maxillary-mandibular anterior open bite relationship. B: Anterior-posterior relationship of anterior maxilla in relation to the mandible. C: Moment of clinical examination of the newborn's oral cavity; conducted by researcher. Photography: by researcher.

Concerning the newborn's anterior maxillary-mandibular region, patterns can be found such as anterior open bite (Figure 3A), overbite and edge to edge ${ }^{7}$ relationship. When analyzing the anterior-posterior jaw relationship, one may observe three types of patterns: anteriorly-positioned maxilla (Figure 3B), anteriorly-positioned mandible and edge to edge 4,10 .

Cetinkaya et al. ${ }^{1}$ studied the correlation between the features and variations found in the newborn's oral cavity whose mothers had medical complications during pregnancy, systemic diseases, such as diabetes, smoked, or took drugs during pregnancy or whose parents were consanguineous. They found that all of these factors were related to the prevalence of oral cysts.

Few studies have been devoted to researching the features present in the newborn's oral cavity and its relationship with maternal and neonatal variables. However, a variety of anomalies may be found in this population $n^{1-3,7,11-13}$.

The objective of this research was to determine the characteristics and prevalence of intraoral findings in a group of Brazilian newborns up to three days old and treated at a university hospital. Also, it has the objective of relating the characteristics and prevalence of these findings to the neonatal and parent variables. 


\section{MATERIALS AND METHODS}

\section{Design and Ethical Aspects}

This is a cross-sectional study on intraoral findings in newborns. It was approved by the Ethics in Research Committee of the Federal University of Rio Grande do Norte (UFRN) (154.438/2012). The mothers were informed about the study's objectives and methods and agreed to their and their child's participation by signing a consent form.

\section{Sample}

A non-probability sample was selected from newborns up to three days old, of both sexes, born between January and December 2013 in the Ana Bezerra University Hospital, in the city of Santa Cruz-RN (Brazil). Children with an Apgar score less than 6 at the fifth minute of life, or premature ${ }^{1}$ children who had syndromes or systemic disorders that required intensive treatment ${ }^{11}$ were not sampled.

Medical information concerning the date of birth, gestational age, sex, birth weight and adaptation assessment score of the newborn (through the Apgar score, where the respiratory rate, heart rate, crying, perfusion and muscular tonus are taken into consideration) ${ }^{14}$ were scored as neonatal variables. Habits such as smoking and/or use of alcohol, in addition to age, health during pregnancy, systemic diseases, and any medical drugs that were used during pregnancy and type of delivery were scored as maternal variables. Additionally, information about the male genitor's habits and general health were also included. There was no exposure of the participants involved because their identities were kept confidential.

\section{Data Gathering Procedures}

The dental examination of the newborn's oral cavity was performed by a single investigator, who was trained based on literature data, including photos. The examination took place in a bright and airy place, the Ana Bezerra University Hospital's infirmary. For the exam, the following items were used: dental mirror number 3 , flashlight, extraoral flexible plastic ruler. In addition, the researcher used full protective equipment. The baby's mouth was gently opened by the researcher's gloved finger, and the analysis was made by visual clinical examination. The child was examined in his/her own standard crib, under artificial light (Figure 3C).

Data of the newborn's clinical examination were entered in a clinical record. Additionally, the data collected from medical records during the interview, about data about the overall health of the newborn and his/her parents were also entered in the clinical record.

\section{Study Variables}

The intraoral findings variables studied were the fibrous cord of Robin and Magitot, inclusion cysts, the labial and lingual frenulum and relationship of alveolar ridges. The neonatal exposure variables were: sex (female or male), weight in kilograms (Above normal, Below normal, Suitable) ${ }^{15}$, gestational age (years), Apgar Score $\left(\geq 6^{\text {th }}\right.$ minute and $<6^{\text {th }}$ minute) and type of delivery (vaginal or cesarian). The parent variables were antibiotic use during pregnancy (yes or no), tobacco use during pregnancy (yes or no), alcohol use during pregnancy (yes or no), gestational diabetes (yes or no), consanguinity between the parents (yes or no), mother's age ( $\leq 19$ years, between 20-34 years, $\geq 35$ years), tobacco use by the father (yes or no), alcohol use by the father (yes or no). 


\section{Statistical Analysis}

The data were recorded in a database and analyzed using Statistical Package for Social Science - SPSS ${ }^{\circledR} 17.0$ (SPSS Inc., Chicago, USA). The results were presented descriptively, establishing absolute and relative frequencies. Poisson regression was used to estimate the ratio of gross and adjusted prevalence of intraoral findings with neonatal and parent variables. The variable outcomes were intraoral findings (Epstein pearls, Bohn's nodule, dental lamina cyst and ankyloglossia). A confidence interval of $95 \%$ and level of significance of $5 \%$ were adopted.

\section{RESULTS}

Of 168 examined newborns, 73 (43.5\%) were female and 95 (56.5\%) were male. The most prevalent intraoral characteristic was the fibrous cord of Magitot observed in $105(62.5 \%)$ babies. In 70 newborns (41.7\%), the cord was found in the lower flange, in two (1.2\%) it was found in the upper flange, and in $33(19.6 \%)$, it was found simultaneously in the upper and lower flanges (Table 1).

In respect to the labial frenulum insertion, the most common location was the apical insertion on the flange, 124 (73.8\%), followed by the palate, $10(6.0 \%)$, and the buccal insertion, 34 (20.2\%). Ankyloglossia was found in 3 (1.8\%) of the babies.

The most prevalent intraoral alteration was Epstein pearls, found in 75 (44.6\%) newborns. This nodule was white in color in 63 (37.5\%) cases, and most commonly measuring up to $1 \mathrm{~mm}$ in diameter in $47(28.0 \%)$ of the examined babies. Bohn's nodule was observed in $22(13.1 \%)$ patients, most commonly yellow in color, 16 (9.5\%), and measuring up to $1 \mathrm{~mm}$ in $17(6.5 \%)$ babies. The nodule was most frequently located on the buccal gingiva, $19(11.3 \%)$ babies. The dental lamina cyst was the cyst with the lowest prevalence, eight (4.8\%) newborns. This cyst was observed most often with a white color 8 (4.8\%) and measuring less than $1 \mathrm{~mm}$, six (3.6\%) babies.

When the presence of inclusion cysts was evaluated, $82(48.8 \%)$ infants did not show any cysts, $69(41.8 \%)$ had one of the three types, 15 (8.9\%) presented two types and two $(1.2 \%)$ presented with three types.

In the relationship between anterior alveolar ridges, the anterior open bite was the most prevalent with 150 (89.3\%) babies, followed by edge to edge with 13 (7.7\%), and overbite with five (3.0\%), and. In the anterior-posterior relationship, maxillary projection was most prevalent with $162(96.4 \%)$ newborns, followed by edge to edge with five $(3.0 \%)$ and mandibular projection with one $(0.6 \%)$. In this study cases of natal teeth, cleft palate, or babies with sucking pads were not found.

When considering the changes in the normal findings in the oral cavity of newborns, represented by ankyloglossia and the inclusion cyst, it was observed that $81(48.2 \%)$ infants did not show any change, 68 (40.5\%) had at least one of these manifestations, $17(10.1 \%)$ had two alterations and two (1.2\%) newborns had three of these manifestations.

The Poisson probability distribution test was used to estimate the ratio of gross and adjusted prevalence of findings, and it was observed that the alterations in the oral cavity (inclusion cysts and ankyloglossia) have no association with maternal or neonatal variables. Newborn variables were associated with Bohn's Nodule, with female 


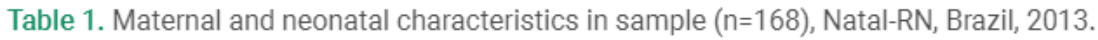

\begin{tabular}{|c|c|c|}
\hline Variables & $\mathrm{n}(\%)$ & mean (SD) \\
\hline \multicolumn{3}{|l|}{ Parent Variables } \\
\hline \multicolumn{3}{|l|}{ Consanguinity } \\
\hline No & $158(94.0)$ & \\
\hline Yes & $10(6.0)$ & \\
\hline \multicolumn{3}{|c|}{ Antibiotic use during pregnancy } \\
\hline No & $105(62.5)$ & \\
\hline Yes & $63(35.7)$ & \\
\hline \multicolumn{3}{|c|}{ Tobacco use during pregnancy } \\
\hline No & $156(92.9)$ & \\
\hline Yes & $12(7.1)$ & \\
\hline \multicolumn{3}{|l|}{ Gestational diabetes } \\
\hline No & $156(92.9)$ & \\
\hline Yes & $12(7.1)$ & \\
\hline \multicolumn{3}{|l|}{ Mother's age } \\
\hline$\geq 35$ years & $13(7.7)$ & \\
\hline $20-34$ years & $116(69.0)$ & $24.51(6.35)$ \\
\hline$\leq 19$ years & $39(23.2)$ & \\
\hline \multicolumn{3}{|l|}{ Tobacco use by the father } \\
\hline No & $138(82.1)$ & \\
\hline Yes & $30(17.9)$ & \\
\hline \multicolumn{3}{|l|}{ Alcohol use by the father } \\
\hline No & $92(54.8)$ & \\
\hline Yes & $76(45.2)$ & \\
\hline \multicolumn{3}{|l|}{ Neonatal variables } \\
\hline \multicolumn{3}{|l|}{ Sex } \\
\hline Female & $73(43.5)$ & \\
\hline Male & $95(56.5)$ & \\
\hline Apgar score ( $6^{\text {th }}$ minute $)$ & & $9.04(0.48)$ \\
\hline Gestational age & & $39.65(1.25)$ \\
\hline \multicolumn{3}{|l|}{ Weight (birth) } \\
\hline Above normal & $13(7.7)$ & \\
\hline Below normal & $50(29.8)$ & $3,318.74(477.40)$ \\
\hline Suitable & $104(61.9)$ & \\
\hline Missing data & $1(0.6)$ & \\
\hline \multicolumn{3}{|l|}{ Type of delivery } \\
\hline Vaginal & $108(64.3)$ & \\
\hline Cesarean & $60(35.7)$ & \\
\hline
\end{tabular}

gender being a protective factor ( $O R=0.90: 95 \% \mathrm{IC}: 0.82-0.99)$. The male genitor variable was associated with Epstein pearls, and no tobacco use by the father was a protective factor (OR=0.73;95\% Cl:0.55-0.97). Lower mother's age, between 20-34 years $(\mathrm{OR}=1.58 ; 95 \% \mathrm{Cl}: 1.07-2.35)$ and 19 years and under $(\mathrm{OR}=1.61 ; 95 \% \mathrm{Cl}: 1.03-2.52)$ increased the chance of having the Epstein pearls (Table 2). 
Table 2. Bivariate analysis and crude and adjusted prevalence ratio (PR) and $95.0 \%$ confidence intervals (Cl) between parents and neonatal variables ( $n=168)$. Natal-RN, Brazil, 2013.

\begin{tabular}{|c|c|c|c|c|c|c|c|}
\hline & \multirow{2}{*}{\multicolumn{2}{|c|}{$\begin{array}{l}\text { Bohn's Nodule } \\
\qquad(n=22)\end{array}$}} & \multicolumn{5}{|c|}{ Intraoral findings } \\
\hline & & & \multicolumn{2}{|c|}{$\begin{array}{l}\text { Epstein pearls } \\
\qquad(\mathrm{n}=75)\end{array}$} & \multicolumn{2}{|c|}{$\begin{array}{l}\text { Dental Lamina Cyst } \\
\qquad(\mathrm{n}=8)\end{array}$} & $\begin{array}{l}\text { Ankyloglossia } \\
(n=3)\end{array}$ \\
\hline $\begin{array}{l}\text { Parent } \\
\text { Variables (Ref) } \\
(n=168)\end{array}$ & $\begin{array}{l}\mathrm{PR}^{\mathrm{b}}(95 \% \mathrm{Cl}) \\
\mathrm{PR}^{\mathrm{a}}(95 \% \mathrm{Cl})\end{array}$ & p-value & $\begin{array}{l}\operatorname{PR}^{b}(95 \% \mathrm{Cl}) \\
\operatorname{PR}^{\mathrm{a}}(95 \% \mathrm{Cl})\end{array}$ & p-value & $\begin{array}{l}\mathrm{PR}^{\mathrm{b}}(95 \% \mathrm{Cl}) \\
\mathrm{PR}^{\mathrm{a}}(95 \% \mathrm{Cl})\end{array}$ & p-value & $\begin{array}{l}\operatorname{PR}^{\mathrm{b}}(95 \% \mathrm{Cl}) \\
\operatorname{PR}^{\mathrm{a}}(95 \% \mathrm{Cl}) \quad \text { p-value }\end{array}$ \\
\hline \multicolumn{8}{|l|}{ Consanguinity } \\
\hline (Yes) & $1.33(0.18-9.88)$ & 0.781 & $1.12(0.41-3.08)$ & 0.821 & - & & - \\
\hline \multicolumn{8}{|l|}{$\begin{array}{l}\text { Antibiotic } \\
\text { use during } \\
\text { pregnancy }\end{array}$} \\
\hline (Yes) & $1.29(0.52-3.15)$ & 0.583 & $0.95(0.60-1.52)$ & 0.835 & $\begin{array}{l}0.36(0.09-1.51) \\
0.96(0.90-1.02)\end{array}$ & $\begin{array}{l}0.162 \\
0.198 \\
\end{array}$ & - \\
\hline \multicolumn{8}{|l|}{$\begin{array}{l}\text { Tobacco } \\
\text { use during } \\
\text { pregnancy }\end{array}$} \\
\hline (Yes) & $1.62(0.22-12.01)$ & 0.639 & $0.64(0.31-1.34)$ & 0.240 & - & & - \\
\hline
\end{tabular}

\begin{tabular}{|c|c|c|c|c|c|c|c|c|}
\hline $\begin{array}{l}\text { Gestational } \\
\text { diabetes }\end{array}$ & & & & & & & & \\
\hline (Yes) & - & & - & & $\begin{array}{l}0.23(0.05-1.14) \\
0.88(0.76-1.00)\end{array}$ & $\begin{array}{l}0.073 \\
0.061 \\
\end{array}$ & - & \\
\hline $\begin{array}{l}\text { Mother's age } \\
\text { ( } \geq 35 \text { years) }\end{array}$ & & & - & & & & - & \\
\hline 20-34 years & $\begin{array}{l}1.14(0.94-1.38) \\
1.14(0.94-1.38)\end{array}$ & $\begin{array}{l}0.186 \\
0.173 \\
\end{array}$ & $\begin{array}{l}1.66(1.12-2.48) \\
1.58(1.07-2.35)\end{array}$ & $\begin{array}{l}0.012 \\
0.023 \\
\end{array}$ & $1.05(0.93-1.19)$ & 0.407 & $1.03(0.95-1.11)$ & 0.504 \\
\hline$\leq 19$ years & $\begin{array}{l}1.20(0.97-1.48) \\
1.17(0.95-1.44)\end{array}$ & $\begin{array}{l}0.094 \\
0.145\end{array}$ & $\begin{array}{l}1.80(1.17-2.79) \\
1.61(1.03-2.52)\end{array}$ & $\begin{array}{l}0.008 \\
0.036\end{array}$ & $1.05(0.92-1.20)$ & 0.442 & $1.00(0.92-1.09)$ & 1.000 \\
\hline $\begin{array}{l}\text { Tobacco use } \\
\text { by the father }\end{array}$ & & & & & & & & \\
\hline (Yes) & $\begin{array}{l}0.47(0.19-1.14) \\
0.91(0.80-1.04)\end{array}$ & $\begin{array}{l}0.095 \\
0.165\end{array}$ & $\begin{array}{l}0.69(0.40-1.17) \\
0.73(0.55-0.97)\end{array}$ & $\begin{array}{l}0.167 \\
0.029\end{array}$ & $0.65(0.13-3.23)$ & 0.601 & - & \\
\hline
\end{tabular}

Alcohol use by

the father

$\begin{array}{lllllll}\text { (Yes) } \quad 0.99(0.43-2.29) & 0.984 & 0.85(0.54-1.33) & 0.477 & 0.83(0.21-3.30) & 0.787\end{array}$

\begin{tabular}{|c|c|c|c|c|c|c|c|c|}
\hline $\begin{array}{l}\text { Neonatal } \\
\text { variables (Ref) } \\
(\mathrm{n}=168)\end{array}$ & & & & & & & & \\
\hline $\begin{array}{l}\text { Sex } \\
\text { (Male) }\end{array}$ & $\begin{array}{l}0.38(0.14-1.04) \\
0.90(0.82-0.99)\end{array}$ & $\begin{array}{l}0.059 \\
0.048 \\
\end{array}$ & $0.87(0.55-1.38)$ & 0.547 & $2.17(0.52-9.08)$ & 0.289 & $2.60(0.24-28.70)$ & 0.435 \\
\hline $\begin{array}{l}\text { Apgar score } \\
\left(\geq 6^{\text {th }} \text { minute }\right)\end{array}$ & $1.24(0.51-3.02)$ & 0.629 & $0.99(0.62-1.59)$ & 0.976 & $\begin{array}{c}2.50(0.61- \\
10.34)\end{array}$ & 0.204 & $0.32(0.06-1.58)$ & 0.162 \\
\hline $\begin{array}{l}\text { Gestational } \\
\text { age (years) }\end{array}$ & $1.12(0.79-1.58)$ & 0.518 & $0.98(0.82-1.17)$ & 0.816 & $1.07(0.61-1.88)$ & 0.814 & $0.82(0.34-2.00)$ & 0.664 \\
\hline \multicolumn{9}{|l|}{$\begin{array}{l}\text { Weight } \\
\text { Above normal }\end{array}$} \\
\hline Below normal & $1.75(0.23-13.31)$ & 0.575 & $\begin{array}{l}1.24(0.81-1.91) \\
1.15(0.76-1.76) \\
\end{array}$ & $\begin{array}{l}0.326 \\
0.513 \\
\end{array}$ & $1.00(0.88-1.14)$ & 0.963 & $1.00(0.92-1.08)$ & 1.000 \\
\hline Suitable & $1.82(0.22-14-79)$ & 0.589 & $\begin{array}{l}1.37(0.92-2.06) \\
1.25(0.84-1.87)\end{array}$ & $\begin{array}{l}0.126 \\
0.277 \\
\end{array}$ & $0.95(0.84-1.08)$ & 0.441 & $1.03(0.95-1.11)$ & 0.458 \\
\hline $\begin{array}{l}\text { Type of delivery } \\
\text { (Cesarean) }\end{array}$ & $1.19(0.48-2.92)$ & 0.703 & $1.18(0.73-1.92)$ & 0.503 & $0.56(0.14-2.22)$ & 0.406 & $0.280 .02-3.06)$ & 0.296 \\
\hline $\begin{array}{l}\text { 95\% Cl (confider } \\
\text { Ref: Reference } \\
\text { PR }^{b} \text { Crude prev } \\
\text { PR }^{\mathrm{a}} \text { Adjusted pr }\end{array}$ & $\begin{array}{l}\text { nce interval) } \\
\text { category. } \\
\text { ralence ratio } \\
\text { revalence ratio }\end{array}$ & & & & & & & \\
\hline
\end{tabular}




\section{DISCUSSION}

The present study has shown a high prevalence of intraoral alterations in newborns. The feature most found in this study was the fibrous cord of Magitot and the most frequent alteration was the inclusion cyst. Moreover, the intraoral findings in newborns were associated with neonatal and parent variables and these associations need to be better examined in future studies.

Our results agree with the literature by showing that the inclusion cysts are reported to be the most prevalent feature in the newborn's oral cavity ${ }^{1,11}$. In this study almost half of the babies showed inclusion cysts, similar to the results found in the literature, with a range in prevalence from $46 \%$ to $99 \% 7,16,17$. This prevalence variance suggests that very different populations were examined, particularly with respect to the age of the studied babies, because many of these findings tend to be rare after the third month of life ${ }^{16,18}$.

The most prevalent intraoral feature was the fibrous cord of Magitot, corroborating with the literature for being the most prevalent and observed intraoral feature in almost all newborns ${ }^{10}$. In our study, ankyloglossia was found in less than $2 \%$ of the infants, a similar, but slightly higher prevalence is observed in the literature, ranging from $4 \%$ to $11 \%^{7}$. Regarding the insertion of the labial frenulum, a result similar to our study's was found by George et al. ${ }^{12}$, with a higher prevalence for the frenulum insertion on the crest of the flange (76.6\%). Nevertheless, their results diverged from ours by indicating palatal insertion as the second most prevalent (16.7\%).

Epstein pearls was the most frequently observed abnormality, followed by the Bohn's nodule and the dental lamina cyst. This result corroborated with the result of Vaz et al. ${ }^{17}$ but was discordant with the result of George et al. ${ }^{12}$, which indicated the Bohn's nodule as the most prevalent inclusion cyst. Research shows that children who are born with a buccal nodule are more likely to have their oral cavity colonized by Streptococcus mutans at an early age and may represent an increased risk of developing caries, because these nodules serve as a site of biofilm accumulation ${ }^{1,19}$.

After birth, it is also possible to observe the presence of sucking pads, a callus that forms at the midline of the upper lip, common in children who are breastfed. However, no baby in this research presented with this finding, probably because they were examined in the early hours of life and it takes some time for the breastfeeding stimulation to give rise to the sucking pads $s^{7,13}$.

No cases of natal or neonatal teeth were found in this study, possibly due to the sample's size, since these findings tend to occur in every 2,000 to $3,000^{7}$ newborns. Natal teeth are already present at childbirth, and neonatal teeth appear in the oral cavity during the first month of life ${ }^{20}$. These teeth are often mobile, allowing for possible aspiration, or potentially causing ulcers on the tongue's ventral surface, which is called Riga Fede disease ${ }^{10}$. Due to these potential risks, the extraction of these teeth should be considered ${ }^{11}$. Natal teeth are considered eruption anomalies and are more frequent in children with genetic disorders and may also be a clinical sign for syndromes ${ }^{10,21}$. 
In this research, evaluating the relationship between anterior alveolar ridges, anterior open bites were the most prevalent, followed by edge to edge relationships and overbites. The data of Abanto et al. ${ }^{7}$ indicate that patterns of edge to edge and overbite relationships are observed less frequently and that the open bite pattern is prevalent ${ }^{7}$. The anterior open bite is a situation considered physiological before tooth eruption and also favorable because it can provide an ideal overbite after tooth eruption? ${ }^{7}$. In the anterior-posterior relationship, maxillary projection was the most prevalent, followed by edge-to-edge and then mandibular projection. Similar results were observed in other studies, they found the projection of the maxilla reaching over $90 \%$ prevalence in relation to the other two patterns of anterior-posterior relationship $4,10,12$.

The intraoral characteristics were not associated with almost any of the newborns or parent variables evaluated. Among the parent variables, Epstein pearls were associated with use of tobacco by the father and gestational age. Regarding newborn variables, Bohn's Nodule was associated with male gender. Cetinkaya et al. ${ }^{1}$ studied the correlation between the features and variations found in the newborn's oral cavity such as medical complications during pregnancy, mother's systemic disease(s), smoking and/or taking drugs during pregnancy and consanguinity between parents. They showed that there is a statistically significant relationship between the prevalence of oral cysts and factors such as diabetes, insulin use during pregnancy, consanguinity between parents and tobacco use during pregnancy ${ }^{1}$. However, these data are inconclusive, since some studies show no statistically significant relationship between the prevalence of the inclusion cyst and the baby's weight ${ }^{7}$, the mothers' age ${ }^{1,3}$, baby's sex ${ }^{11}$, weight when born, gestational age or variables related to the birth ${ }^{11}$, as verified for most of the conditions evaluated in the present study. The factors associated with these oral conditions need to be further explored in future studies.

Despite the evidences found, our study has limitations that should be taken into consideration. First, the sample size does not allow an enhanced evaluation of the great quantity of exposure variables, considering that a model requires at least 17 observations per variable level. Second, the small variability of some variables does not allow inferences about their relationship with intraoral findings. Finally, the evaluation within three days of birth may precede the moment of emergence of other intraoral findings or extension of those already found. Also, the scarcity of research in this area makes the comparison of results limited; more studies are needed to clarify the factors associated with prevalence of intraoral findings in newborns.

A variety of features and alterations can be observed in the newborn's oral cavity and the clinician must learn to identify them to avoid unnecessary treatment and institute appropriate treatment when necessary.

In conclusion, the intraoral feature most found in this study was the fibrous cord of Magitot and the most frequent alteration was the inclusion cyst, with Epstein pearls the most prevalent of these. The newborn male gender, tobacco use by the male genitor and the mother's age were all associated with the presence of abnormal intraoral findings. 


\section{ACKNOWLEDGEMENTS}

The authors thank all the mothers who allowed their infants to participate in this research. Without them the scientific growth through this research would not have been possible.

\section{REFERENCES}

1. Cetinkaya M, Oz FT, Orhan Al, Orhan K, Karabulut B, Karabulut DCC, et al. Prevalence of oral abnormalities in a Turkish newborn Population. Int Dent J. 2011 Apr;61(2):90-100. doi: 10.1111/j.1875-595X.2011.00020.x.

2. Flinck A, Paludan A, Matsson L, Holm AK, Axelsson I. Oral findings in a group of newborn Swedish children. Int J Paediatr Dent. 1994 Jun;4(2):67-73.

3. Santos FFC, Pinho, JRO, Libério SA, Curz MCFN. [Prevalence of congenital and developmental oral abnormalities in infants aged 0 to 6 months]. Rev Odonto Cienc 2009;24(1):77-80. Portuguese.

4. Correa MSN. Odontopediatria na primeira infância. São Paulo: Santos; 2005. p.99-119.

5. Assed S. Odontopediatria: bases científicas para a prática clínica. São Paulo: Artes Médicas; 2005. p.62-5.

6. American Academy of Pediatric Dentistry Council on Clinical Affairs. Guideline on pediatric oral surgery. Pediatr Dent. 2005-2006;27(7 Suppl):158-64

7. Abanto J, Raggio DP, Alves FBT, Corrêa FNP, Bonecker M, Corrêa MSNP. Oral characteristics of newborns: report of some oral anomalies and their treatment. Int J Dent 2009 Jul/Set;8(3):140-5.

8. Fromm A. Epstein's pearls, Bohn's nodules, and inclusioncysts of the oral cavity. J Dent Child. 1967 Jul;34(4):275-87.

9. Kana A, Markou L, Arhakis A, Kotsanos N. Natal and neonatal teeth: a systematic review of prevalence and management. Eur J Paediatr Dent. 2013 Mar;14(1):27-32.

10. Schmitt MHE, Guzzi SH, Damo MN, Araújo SM, Farias MMAG. Characteristics of the oral cavity of the newborns of Blumenau - SC, Brazil. Pesq Bras Odontoped Clin Integr 2012 Jan/Mar;12(1):89-92. doi: 10.4034/PBOCI.2012.121.14.

11. Liu MH, Huang WH. Oral abnormalities in Taiwanese newborns. J Dent Child (Chic). 2004 May-Aug;71(2):118-20.

12. George D, Bhat SS, Hegde K. Oral Findings in Newborn Children in and around Mangalore, Karnataka State, India. Med Princ Pract. 2008;17(5):385-9. doi: 10.1159/000141502.

13. Silva CM, Ramos MM, Carrara CF, Dalben GS. Oral characteristics of newborns. J Dent Child (Chic). 2008 Jan-Apr;75(1):4-6.

14. Apgar V. A proposal for a new method of evaluation of the newborn infant. Curr Res Anesth Analg. 1953 Jul-Aug;32(4):260-7.

15. World Health Organization. Public health aspects of low birth weight: third report of the Expert Committee on Maternal and Child Health. Geneva: World Health Organization; 1961. (WHO Technical Reporter Service, 217).

16. Donley CL, Nelson LP. Comparison of palatal and alveolar cysts of the newborn in premature and full-term infants. Pediatr Dent $2000 \mathrm{Jul} /$ Aug;22(4):321-4

17. Vaz PMN, Vieira FR, Silveira RG, Miasato JM. More frequent oral alterations in the baby: two cases report of inclusion cysts. Rev Odontol Univ Cid S Paulo. 2010 May/Aug;22(2):174-7. 
18. Flaitz CM. [Oral soft tissue disorders pathologies and disorders]. In: Pinkhan JR. [Pediatric dentistry from childhood to adolescence]. São Paulo: Artes Médicas; 1996. Portuguese.

19. Hegde RJ. Sublingual traumatic ulceration due to neonatal teeth (Riga-Fede disease). J Indian Soc Pedod Prev Dent. 2005 Mar;23(1):51-2.

20. Mhaske S, Yuwanati MB, Mhaske A, Ragavendra R, Kamath K, Saawarn S. Natal and Neonatal Teeth: An Overview of the Literature. ISRN Pediatr. 2013 Aug 18;2013:956269. doi: 10.1155/2013/956269.

21. Moyers R. Ortodontia. 3.ed. Rio de Janeiro: Guanabara-Koogan; 1987. 669p. 